\title{
The Language of Street Signs in Dualist Transylvania and the Banat
}

\author{
Ágoston BERECZ \\ European University Institute (Florence, Italy) \\ Department of History and Civilization \\ oguszt@gmail.com
}

\begin{abstract}
Twice in the history of late Habsburg Austria, local conflicts over the languages used on street signs spilled out into all-out political crises on the imperial level - first in 1892, when the Prague municipality's decision to replace the city's bilingual signs with Czech-only ones and to rename a multitude of streets after Czech national heroes sparked violent demonstrations across the Empire's German-speaking cities. Then in 1911, a plan to display street names in three scripts in Sarajevo led to a tug of war between the Bosnian parliament and the imperial authorities. If there were no such high-profile symbolic fights over urban spaces in the contemporary Kingdom of Hungary, that was not because Magyarizing policies had successfully purged the linguistic cityscape, as the earlier literature on the era may lead one to believe. The picture that unfolds from the sources employed here is indeed diverse. But unlike in the western half of the Empire, city fathers were more interested in papering over rather than playing up national conflicts. The story of street signs in Dualist Transylvania and the Banat is one of resistance and consensus, of complex power relations and of subtle ways to signal them.
\end{abstract}

Keywords: Banat, linguistic landscapes, nineteenth century, street names, Transylvania

The languages displayed on street signs are part of the wider phenomenon of urban public signage. In the past twenty years, inscriptions appearing in the street or inside public buildings have become a hotly researched topic in sociolinguistics under the label "linguistic landscapes" (Spolsky 2009: 25). I will use the more appropriate term "linguistic cityscape" in this paper, which has been embraced by a minority of researchers. There are distinctive power mechanisms at play in official signage, a category that includes street signs, as against advertisements or shop signs. The language choices that official signs make, seemingly innocuous indexing of their linguistic environment, can become a particularly rigid form of top-down communication with a strong normative stamp (Landry and Bourhis 
1997). When putting up written signs, municipal authorities cannot help but put forward a normative view of the languages that count as legitimate in public. By virtue of their character as names, the small pragmatic role the language of street names plays in orienting passers-by also reinforces this effect unless, of course, they are put down in a writing system unreadable to a significant number of passers-by. The latter was the case in turn-of-the-century Constantinople, where Turkish names appeared in Arabic script on street signs and the French versions alongside them. These were, therefore, of genuine help at least to local Christians, not to mention foreigners, to whom they could also boost the image of Constantinople as a bustling international metropolis (Strauss 2011: 134). By making choices about the language of official signs, town halls may also assert themselves symbolically as ultimate authorities in the local linguistic scene, with the right of giving public recognition to languages and withholding it from them.

There has been in general little diachronic research on linguistic cityscapes. Of course, urban public signage is not a new phenomenon. What is more, studying it as it changes over time can also reveal such hidden meanings that get lost in oneoff snapshots (Pavlenko and Mullen 2015). Few historians keep their finger on the pulse of the current trends in sociolinguistics, to be sure, but the fundamental problem that such research comes up against is one of methodology. To collect the material at any given present moment, all that one needs is a camera or, short of that, a notepad and a pencil. Go back a few years in time, and a full description becomes impossible. I am aware of just two histories of linguistic cityscapes from the international literature: Pavlenko 2010 on Kyiv/Kiev and Pošeiko 2015 on Daugavpils/Dvinsk. Both of these rely on what visual evidence has survived the vagaries of time in the form of photographs, postcards, and paintings and are available in the archives, in digital repositories, or as book illustrations. Needless to say that no rigorous sampling is feasible on such fragmented evidence.

It increases the methodological challenge when the existing sources are narrative rather than visual, as is the case in the present context. For lack of evidence, I cannot take into account the relative placement of linguistic variants however important that would be (Scollon and Scollon 2003: 120, Azaryahu 2012: 469-470) - let alone the typography and colour of the signs (Järlehed 2017). Local histories of street names are often attentive to changes in the languages that street signs displayed, but few of them come complete with pictures of subsequent generations of street signs, as does Kovács 2013 on Brassó/Braşov/Kronstadt, one remarkable specimen of that genre from the area. Street signs are also very rarely discernible on contemporary photographs and postcards.

Therefore, it is by no means the ambition of this paper to help refine the methodological tools of studying past linguistic cityscapes. Most of my sources only mention the languages that appeared on street signs. Through this narrow prism, I would rather wish to point out a few common performative strategies that 
leaders of Dualist Hungary's minority-majority towns implemented to impute identities to their spaces - in contest of or in broad alignment with the robust state language ideology of the time. This overview, which has grown out of my study of the patterns of language choices in local administration (Berecz 2019), will also highlight the relative autonomy in linguistic matters that smaller and middle-sized towns had in Dualist Hungary.

From the sporadic data available from the long nineteenth century, it seems that state powers seldom had formal means to sanitize linguistic cityscapes and mute locally dominant urban cultures. In what was called Congress Poland, local self-governance was dissolved in the wake of the 1863 uprising, and although the Russian-speaking population was largely limited to a floating group of administrative and military personnel, street names had to be displayed in Cyrillic (Malte 2012: 71), and Polish shop signs were accompanied with Russian translations (Weeks 1996: 101). While it is up for debate how far late Russian imperial linguistic policies represented an outlier, the problem did not loom as large for most nationalizing states as it did for the Romanov Empire on its western peripheries. In contrast, there was neither one centrally promoted state nationalism nor a centrally appointed local administration in the Austrian half of the Dual Austro-Hungarian Empire, also known as Cisleithania. Instead, the languages of signs became one of the principal stakes in the national conflicts that pitted urban élites against each other, and they occupied a more prominent place there than the street names themselves. Disputes about the language of street signs threatened twice to throw the empire into major political upheaval.

The first of these two clamorous affairs broke out in 1892, when Prague's municipal leadership decided to remove the German versions from the city's bilingual street signs. In an already tense climate, this measure could not fail to spark violent demonstrations in German cities across the Empire. It only added oil to the fire that a multitude of Prague streets were to be renamed after Czech heroes. Even more troublingly, the Czech leadership justified its plan using the clever if dishonest reasoning that names were not translatable, and therefore the new street names could likewise not be translated into German. Bringing a lengthy process to an end, in 1896, the Higher Administrative Court (Verwaltungsgerichtshof) finally approved of the city government's decision, to which an angered Prague German Club reacted by calling on German landowners to hang up bilingual street signs at their own cost (Cohen 2006: 111, Stourzh 1985: 112).

A second major incident erupted in 1911, this time not so much between hostile nationalist élites as between regional and central political wills. The parties represented in the parliament of Bosnia-Herzegovina struck an agreement about new Sarajevo street signs, displaying street names in the Roman, the Cyrillic, and the Arabic scripts. By including Arabic, Serbs and Croats partly 
courted the Muslim camp and partly pursued the strategy that I call "three is less than two". By this, I refer to the impression that adding a third language or a third script somehow plays down the more loathsome second one and takes the sting out of the surrender that its inclusion amounts to. Although the majority of literate Muslims in the province may have known only the Arabic script, imperial authorities were reluctant to expand its visibility and vetoed the idea of street signs complete with Arabic versions. They finally caved in, however, under the looming threat of a constitutional crisis (Juzbašić 2002: 255-257).

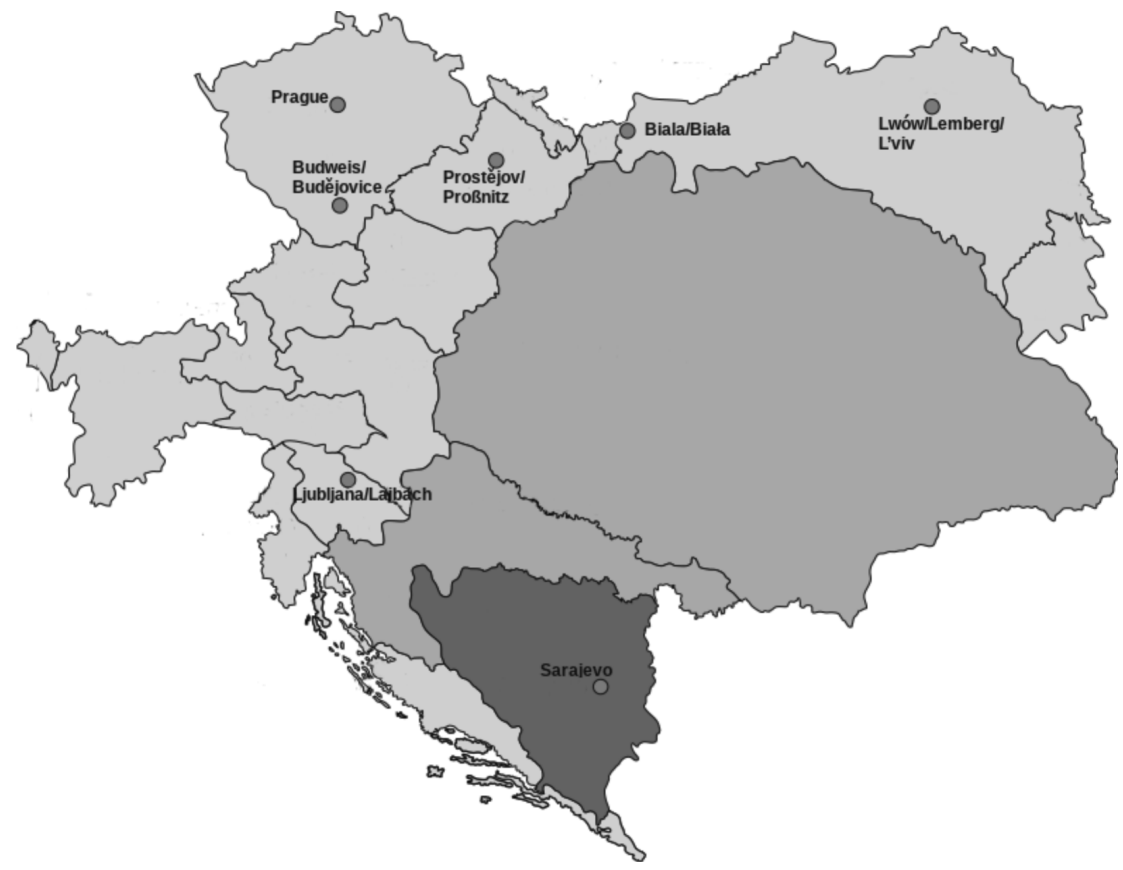

Map 1. Austria-Hungary (1878-1914) with the cities mentioned in the text (the author's work is based on Rowanwindwhistler's map from Wikimedia Commons, CC-BY-SA-3.0)

In Cisleithanian cities, debates over street signs were unabashedly about the possession of public space. The introduction of bilingual signs marked an emancipation of up-and-coming linguistic groups, while through the replacement of bilingual signs with monolingual ones the national movement that had ascended to power thanks to its larger electoral constituency announced its bid for indisputable supremacy (cf. Manussi Montesole 1934: 627-628). In Budweis/ Budějovice, the Czech versions of street names appeared for the first time in 18751876, but, apart from their mostly German referents, the arrangement of the two versions - the German on top and the Czech below - also made the local power 
hierarchy visible (Kovář and Koblasa 2005: 56). ${ }^{1}$ The German town leadership of Prostějov/Proßnitz in Moravia put up bilingual street signs in 1881 in the Christian part of the town, which the new Czech majority hastened to replace with monolingual Czech signs after they came to power in 1892 (Karný 2007: 2-4, Kučerová 2013: 11). In Lwów/Lemberg/L'viv, the earlier German-Polish street signs gave way to Polish signs in the years around 1869, the period when the Polish élite took control over Galicia (Binder 2003: 68). Later, Ruthenian versions were added to some of them as a result of a political compromise between Polish Conservatives and Ruthenian National Populists (Himka 1999: 137). Resentful of their failure to break off from Polish-dominated Galicia and join neighbouring Silesia, the council of Biala/Biała declared the "German character" of this border town in 1884. To validate this principle, it renamed sixty-seven per cent of local street names and put up German street signs in 1890 instead of the earlier bilingual forms (Kisiel 2018: 65-68). Simultaneously with Prague, the city of Ljubljana/ Laibach also introduced monolingual, Slovene-only street signs in 1892. This came in conjunction with a systematic renaming of the city's public spaces. The provincial government (Landesregierung) of Carniola overturned the decision, establishing a violation of Article 19 of the Constitution, which provided for linguistic equality. The case was taken to appeal to the Higher Administrative Court, which ruled - in accordance with the Prague case - that the procedure of the Ljubljana city hall had been constitutional (Stourzh 1985: 110-111).

By the time of the Austro-Hungarian Compromise of 1867, street signs had an established presence in Hungarian cities, but they only cropped up in smaller towns during the second half of the nineteenth century as town halls systematized house numbering and stabilized street nomenclatures. Their spread was propelled as much by administrative rationality and the needs of the postal service as by an urge of beautification and self-representation to visitors. This is shown by the fact that house number plates appeared even where larger-size street signs were absent from street corners. On the other hand, several towns introduced street signs jointly with new artificial, commemorative street names, which had little if any pragmatic justification. Street signs remained an urban phenomenon until the eve of World War One, when they began to penetrate the villages.

While new street names were subject to approval by the Ministry of the Interior, no regulation confined the freedom of local governments to choose the languages of their inscriptions. None, that is, until the 1898 law on locality names made the use of the Hungarian name variants mandatory in any document of an official character and public signage in any language. From the towns mentioned below, Brassó, Lugoj/Lugosch/Lugos, and Orăştie/Szászváros/Broos are known to have printed out their public notices in three languages (Arhivele Naționale ale României Bistrița, Fond Primăria oraşului Bistrița (inv. 619) 341II/1909, 23;

1 On local politics in Budweis, see King 2002. 
ANR Deva, Fond Primăria oraşului Orăştie 1/1904; ANR Braşov, Fond Breasla cizmarilor din Braşov, bundle 22, 163 and bundle 25, 28; Iványi 1907: 127 and Pavlescu 1970: 390). All the towns discussed here but Temeswar/Temesvár/ Timişoara/Temišvar and Werschetz/Vršac/Versec/Vârşeț were overseen by a semi-autonomous county administration, which could therefore interfere with their affairs more readily than the central government.

Hungarian papers often referred to the cityscape as one element of what they called the "character" of a place. In this context, "character" usually came qualified with an ethnonym such as "Magyar", "German", etc. In describing a town, whether from within the borders or abroad, contributors regularly noted the languages of inscriptions alongside with the languages spoken in the street. The connotations of power were not lost on contemporary observers, and, just as in Cisleithania, national activists were more sensitive to the language of street signs than to the referents of street names. The lack of Hungarian versions in particular drew outraged comments, often along the lines of "one does not even feel in Hungary in this town". These voices interpreted the avoidance of Hungarian inscriptions as a slight on the state language, which became a commonplace charge against Transylvanian Saxon town governments during the last twenty years of the era.

The examples that can be cited from Transylvania and the Banat fall into at least three distinct contexts. First, the blank areas of Map 2 mostly stand for majority Hungarian-speaking cities and towns or at least cities and towns where the local councils were dominated by Magyars thanks to the so-called virilism, the automatic representation of the largest taxpayers. Magyars lived in urban localities far beyond their share in the area's overall population, and the extent of their overrepresentation even grew during the Dualist Period. Certainly, many of these cities were more Hungarian to the eye than to the ear - especially on market days - as public signage made minority languages invisible. At least on their street signs, majority Magyar leaderships did not make concessions to local linguistic minorities. However, they may have occasionally put up bi- or trilingual notices, and for several intervals during the 1900s and 1910s official announcements were cried out in two languages in seventy-five percent Magyar Nagybánya/Baia Mare (Nagybánya és Vidéke 18 September 1904, 1 March and 10 August 1913).

In cities of the Banat, a well-heeled German-speaking bourgeoisie steered a judicious middle course between local, Hungarian patriotic, and dynastic-imperial loyalties - even as a minority was pushing for a more radical Magyarization of public spaces. While they were not always responsive to the claims advanced in the name of the state language ideology, they put up little resistance against the inroads of Hungarian. Thus, Hungarian was steadily gaining ground in the symbolic realm, and the Hungarian press routinely hailed new inscriptions as the march of progress. 
The advance of Hungarian took place in ripples. First, the leadership of Temeswar, where a sudden outburst of enthusiasm had already bestowed Hungarian names on some streets in 1848 (Berkeszi 1910: 9), replaced the German signs of the historical centre with bilingual ones after 1875 (Preyer et al. 1875). This move came right on the heels of a decision by the newly united capital, Budapest, to remove the German names from its street signs (Schmall 1906: 107).

Similarly, the new street names introduced in Arad in 1880 likely acted as a stimulus for the council of nearby Lipova/Lippa to replace its earlier GermanHungarian bilingual street signs with Hungarian ones the following year (Familia 25 January/6 February 1881). However, while Hungarian was the preferred language for the bulk of the local people in Arad, its ascendancy could not be more than symbolic in Lipova, a market town numbering 3,335 self-declared native Romanian, 2,459 German, and 721 Hungarian inhabitants at the moment of change, with the last figure probably inflated (Braun 1908: 6). By that time, it boasted a lower secondary school ('polgári iskola'), where parents from the locality and its immediate surroundings sent their sons to pick up some Hungarian before carrying on their studies in a humanistic high school (Pfeiffer 1896: 54). Almost no incoming ten-year-old understood Hungarian in those years (Pfeiffer 1896: 40) and neither did the mayor of the town as late as 1907 (Braun 1908: 29). In such a context, the Hungarian versions of street names had the prominent function to serve as tokens of the locals' loyalty to the status quo, their acceptance of the primacy of Hungarian. To a lesser or greater extent, the same applied throughout the Banat.

In another historically Romanian-German town, Lugoj, Hungarian street names were painted alongside the Romanian (in the Lugojul Român neighbourhood) and the German ones (in Deutsch-Lugosch/Németlugos/Lugojul German) starting from 1891 (Jakabffy 1940: 535, Lay 2007). On the one hand, this seems to have been part of a broader facelift of the town, with the streets being resurfaced with tarmac the following year (Iványi 1907: 126). On the other, the new mayor had formerly served as the district administrator, and in that position he orchestrated the introduction of Hungarian into the town assembly minutes in 1886 (KrassóSzörényi Lapok 29 July 1886, Luminatoriulu 23 July/14 August 1886).

In Werschetz, by contrast, it was on the initiative of the local Magyarizing association that Hungarian versions were added to the earlier German and Serbian signs in 1893 (Perjéssy 1910: 23). In the Banat, local "associations disseminating the Hungarian language" were genuinely grassroots groups unlike the FEMKE in Upper Hungary and the EMKE in Transylvania. Their goals included reshaping the linguistic cityscape although they made a rather modest immediate impact in this field. Their most celebrated achievement was when the Temeswar association replaced nearly a hundred German shop signs free of charge in 1902 (Lendvai 1909: 78). 
Other towns, notably Vajdahunyad/Hunedoara and Brassó/Braşov, were getting "Magyarized" in a different manner - not through the identity change of local Germans but because of the influx of Hungarian-speaking industrial workforce. The Vajdahunyad town hall put up Hungarian-only street signs in 1906 (Hunyadvármegye, 2 August 1906), at a time when Magyars were turning into a local majority due to the local ironworks. Although the town was still led by Romanian mayor George Danilă, non-Romanian members had certainly secured a grip over the municipal council (Dénes, ed. 1909: 39-40).

Trilingual street signs were introduced in Orăştie sometime after 1889, the year when Saxon, Magyar, and Romanian members first reached near-equality in the local council and struck a deal on the trilingual administration of their town ('Dela oraş' [From the town], Libertatea 5/18 October 1902). Their consistently trilingual communications policy, which mirrored the local ethnic make-up, was quite unparalleled in the area. Remarkably, it proved workable in spite of the commitment of the county apparatus to the state nationalist agenda. A similar decision in Brassó should be interpreted against the backdrop of the thoroughly German conduct of business at the town hall although the inhabitants were divided to three almost equal parts according to their native tongues (Kovács 2013: 12-13). The new, trilingual street signs played on the "three is less than two" principle - the Saxon élite controlling the city would likely not have added Romanian versions had they not felt the pressure to introduce Hungarian ones. Observing ostentatious respect for the linguistic rights of Romanians had become part of the Saxon town leaderships' habitual strategy to resist attempts at the linguistic Magyarization of their official life, even though Sextil Puşcariu later complained that the Romanian versions were translated from the German names in Brassó, often to the detriment of existing vernacular Romanian ones (Puşcariu 2001: 125).

Transylvanian Saxon patricians, firmly in the saddle in the former cities of the Saxon Land, experienced every inch yielded to the dominance of Hungarian as a painful loss to their collective heritage. Moreover, the Saxon majorities in the county administrations and Saxon political representation in the government party went a long way towards shielding them from encroachments from above. The delaying tactic of Schäßburg/Sighişoara/Segesvár and Hermannstadt/Sibiu/ Nagyszeben in the immediate pre-war years gives an idea of how much latitude they had. Under pressure from the local Magyar association, the Saxon majority in the former town passed a decision in 1909 to replace its German street signs with trilingual ones, but they did not follow through until 1912, when they postponed implementation indefinitely on the excuse that some of their streets had not yet had names in any language (Az Ujság 22 December 1908, 10 November 1910; Vármegyei Hiradó 20 June 1909; Városok Lapja 7 (1912): 190; Szemlér 2004: 343). In the latter town, the leadership obstructed a motion for at least three years 
between 1910 and 1913 to add Hungarian translations (Pesti Hirlap 15 November 1910, p. 9; Budapesti Hirlap 30 November 1913, p. 31).

In smaller Saxon towns with fewer Magyar residents, town governments may have felt even less reason to change their German-only street signs; these were still in place in Mediasch/Mediaş/Medgyes in 1902 (Hainiss 1902: 23), and the town of Bistritz/Bistrița/Beszterce even commissioned new ones in 1903 (Biró 1992: 108, Hangay 1903: 108).

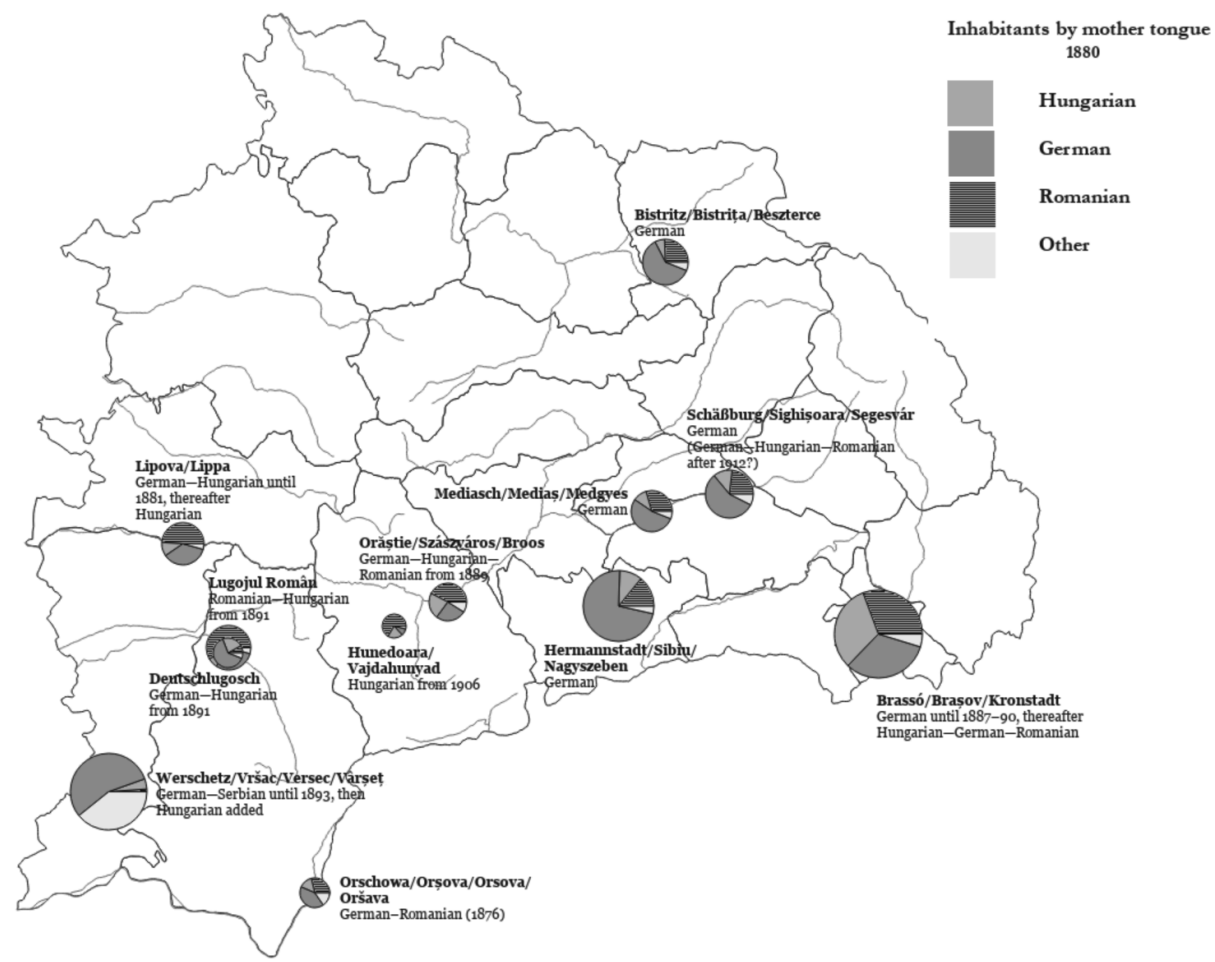

Map 2. The location and linguistic make-up of the mentioned cities and towns (The mother-tongue data are taken from Anonymous 1882.

On Orschowa, Balogh 1876: 595)

In conclusion, especially urban Catholic Germans used Hungarian inscriptions to signal their compliance with the dominant cultural agenda and demonstrate the harmless nature of their otherness. It apparently sufficed to add Hungarian versions to the existing ones even in cities under direct government supervision such as Temeswar and Werschetz. Maintaining the local languages on their signs allowed local élites to emphasize their authentic self-identity and unbroken connection to local values and may have given genuine help to people from the German-, Romanian-, and Serbian-speaking hinterland of these towns. 
Transylvanian Saxon and Magyar city fathers, at the same time, held on to monolingual signs even in otherwise multilingual environments as these were understood to represent the power of their groups. In yielding to pressure, as seen on the example of Brassó, minority-majority town governments could also resort to the "three is less than one" strategy, deflecting the message by foregrounding the pragmatic function of public languages. In a revealing manner, none of these towns enacted explicit rules about public language use, which throws into relief the performative character of these language choices.

Although press coverage of the prolonged tugs-of-war in Cisleithanian cities certainly did not fall on deaf ears in Hungary, no side was ready to come to blows over the languages of street signs, let alone to blow up local incidents into highprofile, all-out conflicts. The sway of Hungarian/Magyar state nationalism was more formidable than any locally or regionally dominant culture could aspire for in Cisleithania, and it left little room for rival ethno-cultural agendas to score victories in this domain. While the possibility of posturing added to the appeal that the issue had for Czech and German municipal leaders in the Bohemian lands, quiet obstruction and playing for time promised more success in Hungary for local élites that strove to keep control of their traditional home turf.

On the opposite side, government agencies were also unwilling to overstep their powers and infringe upon municipal autonomy in issues that were out of sight to the core of the Hungarian-reading public. County authorities could more easily do so, and it probably mattered whether a given town was subordinated to a county leadership sympathetic to the state language ideology or critical of it. But there again, only at the very end of the era did a county formally impose Hungarian in its jurisdiction. The leadership of the thirty percent Magyar KisKüküllő County issued an order in 1910 commanding towns and villages to give Hungarian names to their streets (Vármegyei Hiradó, 23 October 1910). The overwhelming majority of these places had neither official street names at this point nor street signs in any language, and I do not know what - if anything came out of this order.

\title{
References
}

\section{Newspapers and Periodicals}

\author{
Az Ujság \\ Budapesti Hirlap \\ Familia \\ Hunyadvármegye \\ Krassó-Szörényi Lapok
}




\section{Libertatea}

Luminatoriulu

Nagybánya és Vidéke

Pesti Hirlap

Vármegyei Hiradó

Városok Lapja

\section{Other sources}

Anonymous. 1882. A Magyar Korona Országaiban az 1881. év elején végrehajtott népszámlálás eredményei [Results of the Census Conducted in the Lands of the Hungarian Crown, at the Beginning of 1881], 2 vols. Budapest: Országos Magyar Kir. Statisztikai Hivatal.

Azaryahu, Maoz. 2012. Hebrew, Arabic, English: The politics of multilingual street signs in Israeli cities. Social and Cultural Geography 13: 461-479.

Balogh, Kálmán. 1876. A IX. Statisztikai Kongresszus tagjainak kirándulása [Excursion of the participants of the Ninth Congress of Statistics]. Vasárnapi Ujság 23: 593-595.

Berecz, Ágoston. 2019. German and Romanian in town governments of Dualist Transylvania and the Banat. In Carl Bethke-Markian Prokopovych-Tamara Scheer (eds), Language Diversity in the Late Habsburg Empire, 135-159. Leiden: Brill.

Berkeszi, István. 1910. A Delejtú: Délmagyarország első magyar hirlapjának kritikai ismertetése a kor jellemzésével (1858-1861) [Delejtú: A critical presentation of Southern Hungary's first Hungarian-language newspaper with a portrayal of its era (1858-1861)]. Történelmi és Régészeti Értesítő 26 (1910): 1-93.

Binder, Harald. 2003. Making and defending a Polish town: Lwów (Lemberg), 1848-1914. Austrian History Yearbook 34: 57-81.

Biró, Sándor. 1992. The Nationalities Problem in Transylvania, 1867-1940: A Social History of the Romanian Minority under Hungarian Rule, 1867-1918, and the Hungarian Minority under Romanian Rule, 1918-1940. Trans. Mario D. Fenyo. Boulder, Colo.: Social Science Monographs.

Braun, Róbert. 1908. Lippa és Sansepolcro [Lipova/Lippa and Sansepolcro]. Budapest: Deutsch.

Cohen, Gary B. 2006. The Politics of Ethnic Survival: Germans in Prague, 18611914. $2^{\text {nd }}$ rev. ed. West Lafayette, Ind.: Purdue University Press.

Dénes, Károly, ed. 1909. Hunyadvármegyei almanach 1909 [Hunyad County Almanac]. Déva [Deva]: self-published.

Ficzay, Dénes. 2005. Válogatott írások: Séták, rejtélyek, utcanevek és mások [Collected Writings: Walks, Mysteries, Street Names, and More]. Arad: Aradi Kölcsey Egyesület. 
Hainiss, Géza. 1902. Balneologiai tanulmányút Erdélyben [A balneological research trip to Transylvania]. Erdély, III. A Mi Fürdôink [Our Spas], 3-5, 22-26.

Hangay, Oktáv. 1903. Harcz a magyarságért! Az Alldeutsch Szövetség (Alldeutscher Verband) [Struggle for Magyardom! The Alldeutscher Verband]. Kolozsvár [Cluj-Napoca]: Gámán.

Himka, John-Paul. 1999. Religion and Nationality in Western Ukraine: The Greek Catholic Church and the Ruthenian National Movement in Galicia, 1867-1900. Montreal: McGill-Queen's University Press.

Iványi, István. 1907. Lugos rendezett tanácsú város története: adatok és vázlatok [The History of Lugos/Lugoj/Lugosch Town with Settled Council: Data and Sketches]. Szabadka [Subotica]: Horváth.

Jakabffy, Elemér. 1940. Krassó-Szörény vármegye története: különös tekintettel a nemzetiségi kérdésre [The history of Krassó-Szörény County: With special regard to the nationalities problem]. Magyar Kisebbség 20: 352-364, 382-398, 421-433, 456-463.

Järlehed, Johan. 2017. Genre and metacultural displays: The case of street-name signs. Linguistic Landscape 3: 286-305.

Juzbašić, Dževad. 2002. Die Sprachenpolitik der österreichisch-ungarischen Verwaltung und die nationalen Verhältnisse in Bosnien-Herzegowina, 18781918. Südost-Forschungen 61-62: 235-272.

Karný, Léon. 2007. Historie prostějovských ulic [History of the Streets of Prostějov]. Prostějov: Státní Okresní Archiv Prostějov.

King, Jeremy. 2002. Budweisers into Czechs and Germans: A Local History of Bohemian Politics. Princeton: Princeton University Press.

Kisiel, Piotr Szczepan. 2018. Politics of Space in Prussian and Austro-Hungarian Cities. Marburg: Herder-Institut.

Kovács, Lehel István. 2013. Brassó magyar közterületnevei [The Hungarian Hodonymy of Braşov/Brassó/Kronstadt]. Brassó [Braşov]: self-published.

Kovář, Daniel-Pavel Koblasa. 2005. Ulicemi města Českých Budějovic: Názvy českobudějovických veřejných prostranství v minulosti a dnes [The streets of České Budějovice: Public Spaces in České Budějovice in the Past and Today]. České Budějovice: Veduta.

Kučerová, Lucie. 2013. Prostějovské historické stavby v kontextu dějin města [Historic Buildings of Prostějov in the Context of Local History]. Diploma thesis. PalackýUniversity,Olomouc.http://theses.cz/id/4ps45e/00174369-980715926. pdf (last accessed on: 23 July 2019).

Landry, Rodrigue-Richard Y. Bourhis. 1997. Linguistic landscape and ethnolinguistic vitality: An empirical study. Journal of Language and Social Psychology 16: 23-49. 
Lay, Heinrich. 2007. Denumirea străzilor lugojene din cele mai vechi timpuri până în prezent [Street Names of Lugoj/Lugosch/Lugos from the Oldest Times up to the Present]. Töging a. Inn: n. p.

Lendvai, Miklós. 1909. Nemzeti kulturmunka: a temesvári magyar nyelvet terjesztố egyesület negyedszázados múködése [National Cultural Work: A Quarter of a Century of the Temeswar Association Disseminating the Hungarian Language]. Temesvár [Timişoara]: Unió.

Malte, Rolf. 2012. Russifizierung, Depolonisierung oder innerer Staatsaufbau? Konzepte imperialer Herrschaft im Königreich Polen (1863-1915). In Zaur Gasimov (ed.), Kampf um Wort und Schrift: Russifizierung in Osteuropa im 19.-20. Jahrhundert, 51-87. Göttingen: Vandenhoeck und Ruprecht.

Manussi Montesole, Alfred. 1934. Die Adrialänder. In Karl Gottfried Hugelmann (ed.), Das Nationalitätenrecht des altes Österreich, 569-684. Vienna: Braumüller.

Pavlenko, Aneta. 2010. Linguistic landscape of Kyiv, Ukraine: A diachronic study. In Elana Shohamy-Eliezer Ben-Rafael-Monica Barni (eds), Linguistic Landscape in the City, 133-150. Bristol: Multilingual Matters.

Pavlenko, Aneta-Alex Mullen. 2015. Why diachronicity matters in the study of linguistic landscapes. Linguistic Landscape 1: 114-132.

Pavlescu, Eugen. 1970. Meşteşug şi negoț la românii din sudul Transilvaniei (sec. XVII-XIX) [Crafts and Commerce among the Romanians of Southern Transylvania, $17^{\text {th }}-19^{\text {th }}$ Centuries]. Bucharest: Editura Academiei.

Perjéssy, Lajos. 1910. A Verseczi Magyar Közmúvelődési Egyesület története: 1885-1910 [The History of the Hungarian Cultural Association of Werschetz/ Vršac/Versec/Vârşeț: 1885-1910]. Versecz [Vršac]: Kirchner.

Pfeiffer, János. 1896. A lippai állami polgári és felső kereskedelmi iskola története 1874-1896 [History of the Lippa state civil and upper commercial school]. In Pfeiffer, János (ed.), A lippai állami polgári és felsókereskedelmi iskola értesitôje az 1895/96. iskolai évról [The 1895/96 Yearbook of the Lippa State Civil and Upper Commercial School], 3-196. Arad: Réthy.

Pošeiko, Solvita. 2015. The Latvian language in the linguistic landscape of Daugavpils (the middle of the $19^{\text {th }}$ century-today). Journal of Education Culture and Society 6(2): 320-336.

Preyer, János et al. 1875. Temesvár város tereinek és utczáinak uj elnevezése [New names of the squares and streets of Temeswar/Temesvár/Timişoara/Temišvar]. Történelmi és Régészeti Értesító 1: 26-34.

Puşcariu, Sextil. 2001. Braşovul de altădată [The Brassó/Braşov/Kronstadt of Yore]. Braşov: Schei.

Schmall, Lajos. 1906. Buda-Pest utczái és terei: adatok a buda-pesti utczák és terek elnevezéséhez és történetéhez [Streets and Squares of Budapest: Data on 
the Names and History of Budapest Streets and Squares]. Budapest: Budapest székesfőváros házinyomdája.

Scollon, Ron-Suzie Wong Scollon. 2003. Discourses in Place: Language in the Material World. London: Routledge.

Spolsky, Bernard. 2009. Prolegomena to a sociolinguistic theory of public signage. In Elana Shohamy-Durk Gorter (eds), Linguistic Landscape: Expanding the Scenery, 25-39. New York: Routledge.

Stourzh, Gerald. 1985. Die Gleichberechtigung der Nationalitäten in der Verfassung und Verwaltung Österreichs: 1848-1918. Vienna: Austrian Academy of Sciences.

Strauss, Johann. 2011. Linguistic diversity and everyday life in the Ottoman cities of the Eastern Mediterranean and the Balkans (late $19^{\text {th }}$-early $20^{\text {th }}$ century). The History of the Family 16: 126-41.

Szemlér, Ferenc. 2004. Nagyapám, a proconsul [My grandfather, the proconsul]. In Béla Pomogáts (ed.), Vajúdó idók küszöbén: erdélyi magyar írók történelmi elbeszélései [On the Threshold of Times in Travail: Historical Short Stories by Transylvanian Hungarian Authors], 339-354. Budapest: Noran.

Weeks, Theodore R. 1996. Nation and State in Late Imperial Russia: Nationalism and Russification on the Western Frontier, 1863-1914. DeKalb, Ill.: Northern Illinois University Press. 